\title{
UJI AKTIVITAS EKSTRAK DAUN PIRDOT (Saurauia vulcani Korth) TERHADAP PERTUMBUHAN BAKTERI Bacillus subtilis
}

\author{
Ulfayani Mayasari ${ }^{1}$, Agus Vera Berutu ${ }^{2}$ \\ ${ }^{1}$ Program Studi Biologi, Fakultas Sains dan Teknologi, UIN Sumatera Utara Medan \\ ulfayani.mayasari@uinsu.ac.id
}

\begin{abstract}
ABSTRAK
Pirdot is a plant that has been widely used by people to treat various diseases. Pirdot leaves extract contain of flavonoids which have antibacterial Substances. This research has a purpose to determine the activity of pirdot leaves extract (Saurauia vulcani Korth.) inhibit to bacterium Bacillus subtilis. This research uses an experimental method that are the maceration extraction method and testing the antibacterial activity by agar diffusion method. Result of the research was found that the inhibition area of pirdot leaves extract against Bacillus subtilis bacteria that have some clear zone were $8.66 \mathrm{~mm}$, $9.43 \mathrm{~mm}, 9.90 \mathrm{~mm}, 10.97 \mathrm{~mm}$ and $11.66 \mathrm{~mm}$. Pirdot leaves can inhibit the growth of Bacillus subtilis bacteria.
\end{abstract}

Keywords: Pirdot leaf, Bacillus subtilis, antibacterial.

\section{PENDAHULUAN}

Indonesia merupakan Negara yang terdiri dari kurang lebih 65\% perairan dan $35 \%$ daratan dengan iklim tropis, memungkinkan tumbuhnya berbagai tanaman yang dapat dimanfaatkan untuk pengobatan secara tradisional. (Sasmito, 2017). Masyarakat Indonesia sudah sejak lama menggunakan tumbuhan sebagai pengobatan maupun untuk pemeliharaan kesehatan, salah satunya adalah tumbuhan pirdot.

Berdasarkan data empiris, daun pirdot oleh masyarakat sekitar Tigarunggu, Kabupaten Simalungun, Sumatera Utara dipercaya memiliki khasiat untuk menyembuhkan luka dengan cara diperas dan juga pengobatan penyakit gula (Diabetes Melitus) dengan cara direbus (Lovena, 2018). Tumbuhan pirdot belum banyak diteliti dan dikaji secara mendalam, namun banyak tumbuh dan digunakan oleh masyarakat di daerah Sumatera Utara dan Minahasa,
Manado. (Suparman, dkk, 2018). Pirdot merupakan salah satu tumbuhan obat alami yang memiliki khasiat sebagai antibakteri. Pada ekstrak daun pirdot mengandung flavonoid yang berkhasiat sebagai antibakteri (Manurung, dkk, 2016).

Bacillus subtilis merupakan kelompok bakteri Gram positif, aerobik dan mampu untuk membentuk endospore bersifat saprofit yang lazim terdapat dalam tanah, air dan udara serta tumbuh-tumbuhan. Bakteri ini dapat menyebabkan penyakit meningitis, endocarditis, infeksi mata dan lain-lain (Rahmawati, 2015). Bakteri Bacillus subtilis memiliki bentuk morfologi berupa batang dan merupakan bakteri yang dapat ditemukan disaluran pencernaan seperti di dalam usus, apabila jumlah bakteri ini terlalu banyak di dalam usus maka mampu menyebabkan penyakit diare yang ditularkan melalui kontaminasi makanan (Arumbinang, dkk, 2017). 
Pada penelitian sebelumnya sudah dilakukan penelitian daun pirdot terhadap bakteri Escherichia coli dan didapatkan kesimpulan bahwa daun pirdot dapat menghambat bakteri Escherichia coli pada konsentrasi 17,5\% dengan diameter 14,08 $\mathrm{mm}$ dan $20 \%$ dengan diameter $15,43 \mathrm{~mm}$ (Lumban Gaol, 2016). Dan pada penelitian Novia Andriani Sormin juga telah dilakukan penelitian ekstrak daun pirdot terhadap pertumbuhan bakteri Staphylococcus aureus dan Escherichia coli. Dan didapatkan kesimpulan dari hasil uji antibakteri ekstrak etanol daun pirdot terhadap bakteri Staphylococcus aureus diperoleh KHM 10 mg/ml dengan diameter 6,48 $\mathrm{mm}$ dan bakteri Escherichia coli diperoleh $\mathrm{KHM} 10 \mathrm{mg} / \mathrm{ml}$ dengan diameter 6,10 mm.

\section{METODE PENELITIAN}

Penelitian ini menggunakan metode ekperimental, dengan metode ekstraksi secara maserasi dan metode pengujian aktivitas antibakteri secara difusi agar untuk melihat aktivitas dari ekstrak daun pirdot (Sauraniavulcani korth) dalam menghambat pertumbuhan bakteri Bacillus subtilis. Penelitian dilakukan di Laboratorium Mikrobiologi fakultas Farmasi dan Ilmu Kesehatan Universitas Sari Mutiara Indonesia Medan.

Alat-alat yang digunakan diantaranya, autoklaf, batang pengaduk, beaker gelas, bunsen, cawan petri, corong, deg gelas, desikalator, Erlenmeyer, gelas ukur, hot plate, inkubator, jangka sorong, jarum ose, kaca objek, kertas perkamen, kertas saring, krus porselin, lemari pendingin, mikropipet, neraca analitik, oven, penangas air, pecadang kertas, penjepit krus porselin, penjepit tabung, pinset, pipet tetes, rak tabung, spatula, tanur, tabung reaksi. Bahan-bahan yang digunakan diantaranya daun pirdot, etanol 96\%, aquadest, larutan $\mathrm{NaCl}$, bakteri Bacillus subtilis, media Nutrient Agar, media Muller Hinton Agar, larutan Mc Farland.

Sampel daun pirdot diambil secara purposive dari daerah Sigotom Julu, Kecamatan Pangaribuan, Kabupaten Tapanuli Utara lalu dipilih daun yang segar untuk dilakukan pengeringan dan ekstraknya dapat dipakai sebagai bahan penelitian.

Pembuatan simplisia yaitu dengan mengumpulkan daun pirdot segar, lalu disortasi basah, dicuci dengan air mengalir sampai bersih, ditiriskan lalu ditimbang (berat basah $5 \mathrm{~kg}$ ), kemudian dikeringkan di oven dengan suhu $40-50^{\circ} \mathrm{C}$. Simplisia yang telah kering disortasi dan ditimbang berat kering. Simplisia kering selanjutnya dihaluskan dengan menggunakan blender, serbuk simplisia disimpan dalam wadah kaca untuk mencegah pengaruh lembab dan pengotoran lainnya.

Penyarian dilakukan secara maserasi dengan menimbang $500 \mathrm{~g}$ serbuk dimasukkan kedalam maserator, ditambahkan etanol 95\% sebanyak 3,5 liter, tutup dan biarkan selama 5 hari terlindung dari cahaya sambil sering 
diaduk, serkai, peras, cuci ampas dengan cairan penyari secukupnya hingga diperoleh 100 bagian. Maserat dipisahkan kedalam bejana tertutup, biarkan ditempat sejuk, terlindung dari cahaya selama 2 hari. Enap tuangkan atau saring. Suling atau uapkan maserat pada tekanan rendah pada suhu tidak lebih dari $50^{\circ} \mathrm{C}$ hingga konsistensi yang dikehendaki (Depkes RI 1979).

Selanjutnya pembuatan media NA (nutrient agar) dilakukan dengan menimbang sebanyak 20 g serbuk dilarutkan dalam 1 liter aquades, dan media MHA (Muller Hinton Agar) sebanyak $34 \mathrm{~g}$ serbuk dilarutkan dalam 1 liter aquades, dipanaskan hingga mendidih dan larut seluruhnya. Media selanjutnya disterilisasi menggunakan autoklaf pada suhu $121^{\circ} \mathrm{C}$ selama 15 menit (Rahmawati, 2015). setelah dingin media disimpan dalam lemari pendingin (Rahmawati, 2015).

Sebanyak $0,1 \mathrm{ml}$ inokulum dimasukkan ke dalam cawan petri steril, setelah itu dituang media MHA yang telah dicairkan sebanyak $20 \mathrm{ml}$ dengan suhu $45-50^{\circ}$ C dihomogenkan dan dibiarkan sampai media memadat. Pada media yang telah padat diletakkan kertas cakram dengan diameter 5 $\mathrm{mm}$ yang telah direndam selama 15 menit terlebih dahulu didalam larutan bahan uji ekstrak daun pirdot dengan konsentrasi 10\%, $15 \%, 20 \%, 25 \%$ dan $30 \%$ di inkubasi pada suhu $35 \pm 2{ }^{\circ} \mathrm{C}$ selama $18-24$ jam. Selanjutnya diukur diameter daerah hambat di sekitar larutan bahan uji dengan menggunakan jangka sorong dan di lakukan sebanyak tiga kali (Ditjen POM, 1995).

\section{HASIL DAN PEMBAHASAN}

Untuk mendapatkan ekstrak daun pirdot dilakukan ekstraksi menggunakan maserasi. Ekstraksi ini bertujuan untuk melarutkan semua zat yang terkandung didalam sampel menggunakan pelarut yang sesuai serta mencegah terjadinya kerusakan pada senyawa-senyawa termolabil. Simplisia sebanyak 500 g dimaserasi dengan menggunakan pelarut etanol 96\% sebanyak 3,5 L selama lima hari dan dimaserasi selama dua hari lagi dengan menggunakan pelarut etanol sebanyak 1,5 L. Lalu dienaptuangkan penggunaan pelarut etanol. Ekstrak kental yang diperoleh sebanyak $95 \mathrm{~g}$, pemekatan berarti peningkatan jumlah senyawa terlarut secara penguapan pelarut tanpa menjadi kondisi kering, maka ekstrak yang diperoleh hanya menjadi kental dan pekat. .

Pengujian aktivitas antibakteri ekstrak daun pirdot (Saurania vulcani Korth.) dilakukan untuk mengetahui kekuatan dari ekstrak daun pirdot dalam menghambat pertumbuhan bakteri Bacillus subtilis dengan metode difusi cakram yaitu penentuan sensitivitas bakteri dengan suatu zat tertentu yang kemungkinan memiliki aktivitas antibakteri dengan menggunakan kertas cakram. Zona bening yang terbentuk disekitar kertas cakram menunjukkan bahwa ekstrak daun pirdot (Saurania vulcani Korth.) 
memiliki sifat antibakteri terhadap pertumbuhan bakteri Bacillus subtilis.

Tabel 1. Hasil pengukuran rata-rata diameter zona ekstrak daun pirdot terhadap pertumbuhan bakteri Bacillus subtilis.

\begin{tabular}{cc}
\hline Konsentrasi & $\begin{array}{c}\text { Rata-rata zona } \\
\text { hambat (mm) }\end{array}$ \\
\hline $10 \%$ & 8,66 \\
$15 \%$ & 9,43 \\
$20 \%$ & 9,90 \\
$25 \%$ & 10,76 \\
$30 \%$ & 11,66 \\
\hline
\end{tabular}

Pengujian antibakteri diawali dengan melakukan pengujian dengan konsentrasi $10 \%$, 15\%, 20\%, 25\%, dan 30\% pada bakteri Bacillus subtilis. Diameter zona hambat pada bakteri Bacillus subtilis pada konsentrasi 10\% adalah $8,66 \mathrm{~mm}$, pada konsentrasi $15 \%$ adalah 9,43 $\mathrm{mm}$, pada konsentrasi $20 \%$ adalah $9,90 \mathrm{~mm}$, pada konsentrasi $25 \%$ adalah $10,76 \mathrm{~mm}$ dan pada konsentrasi 30\% adalah 11,66 $\mathrm{mm}$. Adanya zona hambat yang terbentuk dikarenakan senyawa flavonoid yang terkandung dalam daun pirdot yang bersifat sebagai antibakteri (Manurung, dkk, 2016).

Berdasarkan Farmakope Edisi IV (1995) syarat daerah hambat efektif apabila menghasilkan batas derah hambat dengan diameter lebih kurang $14 \mathrm{~mm}$ sampai $16 \mathrm{~mm}$. Menurut (Fatmawati dan Wiyono, 2012), Kriteria kekuatan daya hambat antibakteri sebagai berikut: diameter zona hambat $5 \mathrm{~mm}$ atau kurang dikategorikan Lemah, zona hambat 5-10 mm dikategorikan Sedang, zona hambat 10-20 mm dikategorikan Kuat dan zona hambat $20 \mathrm{~mm}$ dikategorikan Sangat kuat. Jadi pada penelitian ini menununjukkan pada bakteri Bacillus subtilis dengan konsentrasi 10\% (8,66 mm), 15\% (9,43 mm), $20 \% \quad(9,90 \mathrm{~mm}), \quad 25 \% \quad(10,76 \quad \mathrm{~mm})$ menunjukkan zona hambat kategori Sedang dan 30\% (11,66 $\mathrm{mm})$ menunjukkan zona hambat katergori Kuat. Zona hambat yang paling besar terdapat pada konsentrasi 30\%. Semakin besar konsentrasi dari ekstrak daun pirdot semakin besar pula zona hambat yang terbentuk.

\section{KESIMPULAN}

Ekstrak daun pirdot (Saurania vulcani Korth.) dapat menghambat pertumbuhan bakteri Bacillus subtilis.

\section{SARAN}

Disarankan kepada peneliti selanjutnya untuk menguji perbandingan senyawa kimia yang terdapat pada daun pirdot dengan ekstrak etanol dan pelarut lainnya. Perlu dilakukan penelitian tentang uji aktivitas ekstrak daun pirdot terhadap bakteri lainnya.

\section{DAFTAR PUSTAKA}

Arumbinang Wajdi, Syuhuud, Sri Kasmiyati, Susanti puji Hastuti. 2017. Uji Aktivitas Antibakteri Campuran 
Ekstrak Biji Kelor (Muntingia calabura)

Terhadap Pseudomonas aeruginosa dan

Bacillus subtilis. Universitas Kristen

Satya Wacana. Diponegoro.

Ditjen POM. 1995. Materi Medika Indonesia.

Jilid VI. Jakarta. Departemen Kesehatan RI.

Loneva, Nova Tri, 2018, Efek Antidiabetes Esktrak Air Daun (Saurania vulcani Korth) Secara In Vitro dan In Vivo, Universitas Sumatera Utara.

Lumban gaol, Eva, 2016, Uji Aktivitas Antibakteri dari Ekstrak Daun Pirdot (Saurania vulcani) Terbadap Bakteri Escherichia coli, Universitas Sari Mutiara Indonesia, Medan.

Manurung, Alexander, Yunus Afifuddin, Lamek Marpaung, 2016, Eksplorasi Tumbuban Obat Di Hutan Lindung Lumban Julu Kecamatan Lumban Julu Kabupaten Toba Samosir, Universitas Sumatera Utara, Medan

Marjoni, R. 2016. Dasar-Dasar Fitokimia Untuk Diploma III Farmasi.Jakarta Timur. Cv. Trans

Rahmawati, Meri, 2015, Uji Aktivitas Antimikroba Ekstrak Etanol dan Air Rimpang Pacing (Costus spiralis)
Terhadap Bakteri Escherichia coli, Shigella dysentreriae, Salmonella typhimurium, Bacillus subtillis, Staphylococcus aureus Serta Fungi Candida albicans, UIN Syarif Hidayatuliah, Jakarta.

Sasmito, Ediati, 2017, Imunomodulator Baban Alam, Rapha Publishing, Yogyakarta.

Suparman, Achmad Rante, Murtihapsari Kadarusman, dan Boima Situmeang, 2018, Senyawa Triterpenoid dari Tumbuban Pirdot (Sauralia sp), Universitas Negeri Gorontalo, Gorontalo.

Surbakti, Chemayanti. 2018. Pengaruh Kombinasi Ekstrak Daun Pirdot (Saurania vulcani Korth.) dan Herba Poguntano (Picria Fel- Terrae Lour) Terbadap Kadar SOD,HbAIC, Ekspresi Insulin Pada Tikus Hiperglikemia. Universitas Sumatera Utara. Medan. 